\title{
A STUDY ON CLINICAL FEATURES, AETIOLOGY, OUTCOMES AND PREDICTORS OF MORTALITY AND MORBIDITY IN CHILDREN WITH ACUTE ENCEPHALITIS SYNDROME IN EASTERN INDIA
}

\author{
Rupa Biswas ${ }^{1}$, Tunisha Bhattacharya ${ }^{2}$, Tapas Mondal', Sayani Banerjee ${ }^{4}$, Syamal Kumar Bandyopadhyay 5 \\ ${ }^{1}$ Assistant Professor, Department of Paediatrics, Calcutta National Medical College, Kolkata, West Bengal, India. \\ ${ }^{2}$ Senior Resident, Department of Paediatrics, Calcutta National Medical College, Kolkata, West Bengal, India. \\ $3 J u n i o r$ Resident, Department of Paediatrics, Calcutta National Medical College, Kolkata, West Bengal, India. \\ ${ }^{4}$ B.Sc (Zoology Hons.), Bethune College, Calcutta University, Kolkata, West Bengal, India. \\ 5 Professor, Department of Paediatrics, Calcutta National Medical College, Kolkata, West Bengal, India.
}

\section{ABSTRACT}

\section{BACKGROUND}

Acute Encephalitis Syndrome (AES) is a common condition leading to hospitalisation of children in India. Infective aetiology remains the most common cause till date. Various studies have been conducted to find out the aetiology, but very few studies on the predictors of mortality and morbidity, particularly from east India.

This study was conducted to find out the causes of AES in children, clinical features, short-term outcome and predictors of morbidity and mortality.

\section{MATERIALS AND METHODS}

A prospective, observational study was carried out including children aged between 1 - 12 yrs. with AES admitted to the Paediatric Intensive Care Unit of a tertiary care hospital in eastern India. Duration of study was one year (June 2016 - May 2017). Total 109 children were enrolled. Aetiology and outcome were evaluated. Data was analysed by SPSS version 16.0, IBM, USA. Chi-square test was applied at $5 \%$ significance level.

\section{RESULTS}

Among 109 children, 11 children left against medical advice. Total 98 children were included in this study. Out of these 40 (40.8\%) were below 5 yrs., 57 (58.2\%) were male and 41 (41.8\%) were female. Apart from fever most common presenting feature was vomiting $(86.7 \%)$ followed by convulsions (84.7\%) and altered sensorium (82.7\%). Bacterial meningoencephalitis was the most common aetiology (45.9\%) followed by viral encephalitis (29.6\%) and in $24.5 \%$ cases no aetiology could be identified. Most common sequelae were seizure $(28.9 \%)$ followed by weakness $(11.8 \%)$ and aphasia $(9.2 \%)$. Outcome was complete recovery (52\%), sequelae $(25.5 \%)$ and death $(22.5 \%)$. Low GCS $<8$, shock and patient requiring mechanical ventilation were associated with poor outcome.

\section{CONCLUSION}

Bacterial meningoencephalitis and viral encephalitis are common causes of AES. Low GCS, shock and mechanical ventilation were independent predictors for mortality in children.

\section{KEY WORDS}

AES, Outcome, Mortality, Sequelae.

HOW TO CITE THIS ARTICLE: Biswas R, Bhattacharya T, Mondal T, et al. A study on clinical features, aetiology, outcomes and predictors of mortality and morbidity in children with acute encephalitis syndrome in eastern India. J. Evolution Med. Dent. Sci. 2018;7(41):4462-4466, DOI: 10.14260/jemds/2018/995

\section{BACKGROUND}

Acute Encephalitis Syndrome (AES) is a constellation of clinical signs and/or symptoms, i.e. acute fever with an acute change in mental status and/or new onset of seizures. Other clinical findings include an increased irritability, somnolence or abnormal behaviour greater than that seen with usual febrile illness.[1] These signs suggest an acute inflammation of brain leading to a complex neurological syndrome that causes significant morbidity and mortality. The condition is a medical emergency and is caused by diverse aetiopathologies

'Financial or Other Competing Interest': None.

Submission 28-08-2018, Peer Review 22-09-2018,

Acceptance 28-09-2018, Published 08-10-2018.

Corresponding Author:

Dr. Tunisha Bhattacharya,

Flat No. 1, Sarala Apartment,

129/1A, S. N. Roy Road, Kolkata-700038,

West Bengal, India.

E-mail: tbhattacharya618@gmail.com

DOI: $10.14260 /$ jemds $/ 2018 / 995$

(c) $(\mathrm{P})($ and encompassing various organ systems extending well beyond central nervous system. The clinical features as well as aetiology varies widely across the globe as well as in various areas of same country.(2) Paediatricians in developing countries face major challenge in treating AES due to lack of adequate investigative facilities and wide range of presenting features leading to diagnostic dilemma. Although, viruses are regarded as the major aetiologic agents for AES worldwide, the syndrome can be caused by a varied group of bacterial and parasitic agents as well. The non-specific nature of clinical features further makes the prediction of possible aetiology difficult, thereby causing a delay in institution of appropriate therapy. The paucity of data on the risk factors predicting morbidity and mortality in paediatric AES cases is also well appreciated. This study was conducted in a tertiary care hospital in Eastern India with the objective of documentation of wide variation of aetiology and clinical features in childhood AES. This data was further analysed to find an association of the clinico-aetiological profile with the 
outcome as well as to focus on the predictors of morbidity and mortality in AES.

\section{MATERIALS AND METHODS}

This prospective observational study was conducted in Paediatric Medicine Department of Calcutta National Medical College involving children admitted with AES within a span of one year from June 2016 to May 2017.

All hospitalised children of 1 - 12 years of age with AES were included in the study. Children having evidence of traumatic coma, febrile convulsion, seizure disorder, hypoglycaemia, hypoxia, dyselectrolytemia, uraemia and similar disorders were excluded from the study.

Detailed systemic and neurological examination were done to identify the probable cause and to assess the severity of neurological damage. Baseline investigations were done as per protocol and special investigations like NS1 antigen, IgM antibody against dengue, scrub typhus, serum and CSF IgM for Japanese Encephalitis (JE) virus, CSF PCR for Herpes Simplex Virus (HSV) and Varicella Zoster Virus (VZV), Widal test, geneXpert for Tuberculosis (TB), HIV Elisa, HIV DNA PCR and neuroimaging were done as per facility available.

Patients were managed symptomatically until a definite cause was identified and then treated accordingly.

The clinical course of the patient was followed for a period of twelve months after discharge. Outcome was classified as complete recovery, sequelae development and death. Neurological sequelae were determined by presence of one or more of the following- seizure disorder, memory loss, weakness, behavioural problem, abnormal extrapyramidal movements, aphasia, blindness, deafness and cranial nerve palsy.

Data were analysed by SPSS version 16.0, IBM, USA. Chisquare test was applied at $5 \%$ significance level.

\section{RESULTS}

Total 109 children were admitted with AES during the study period. Eleven children could not be included in the study, as they left against medical advice. Among 98 children, 40 $(40.8 \%)$ cases were below 5 years. Total male patients were $57(58.2 \%)$ and female were 41 (41.8\%) (Table 1$)$.

Most of the patients belonged to lower socioeconomic class $(40.8 \%)$ followed by lower middle class (30.6\%). Majority of cases came from rural areas (57.1\%). Forty-nine (50\%) patients presented during monsoon season, while 20 $(20.4 \%)$ in winter and $15(15.3 \%)$ in summer season (Figure 1).

Bacterial meningoencephalitis was the most common diagnosis seen in 45 (45.9\%) children followed by viral encephalitis in $29(29.6 \%)$ and in $24(24.5 \%)$ cases no aetiology could be identified. Among bacterial meningoencephalitis, Pneumococcus were found in $10(22.2 \%)$ cases, Streptococcus pyogenes in $6(13.3 \%)$, Haemophilus influenzae type B in 6 (13.3\%), Mycobacterium tuberculosis in 4 (8.9\%), Salmonella typhi in $3(6.7 \%)$, Staph. aureus in $2(4.4 \%)$ and E. coli in $2(4.4 \%)$ cases. Scrub typhus was found in $7(15.6 \%)$ cases. In $5(11.1 \%)$ cases, no aetiology could be identified. Among viral encephalitis Japanese Encephalitis was found in 16 (55.5\%) cases, HSV in 5 (17.3\%), Dengue in $3(10.3 \%)$, Varicella zoster in $3(10.3 \%)$ and Measles in $2(6.9 \%)$ cases. In bacterial meningoencephalitis, $20(44.4 \%)$ were in 1 - 5 years' age group, 14 (31.1\%) in 5-9 years and 11 (24.5\%) were in 9-12 years' age group. In viral encephalitis 13 (44.8\%) were in 1-5 years' age group, $12(41.4 \%)$ in $5-9$ years and $4(13.8 \%)$ in 9 12 years' age group. In unspecified group $10(41.7 \%)$ were in 1-5 years, $8(33.3 \%)$ within 5-9 years and $6(25 \%)$ were within 9-12 years' age group.

Apart from fever most common presenting symptom was vomiting (86.7\%) followed by altered sensorium in 81 $(82.7 \%)$, convulsion in $73(74.5 \%)$ and headache in 55 (56.1\%) patients. Meningeal signs were positive in 58 (59\%), raised ICT in 52 (53.1\%), focal neurological signs in 29 $(29.6 \%), \mathrm{GCS}<8$ in $18(18.3 \%)$ and shock was present in 9 (9.1\%) cases.

In this study convulsion developed in $26(89.6 \%)$ cases of viral meningoencephalitis, whereas it was seen in 27 (60\%) cases of bacterial meningoencephalitis and in 20 (83.3\%) cases in unspecified group. Altered sensorium was seen in $27(93.1 \%)$ cases in viral aetiology, $34(75.5 \%)$ cases in bacterial and in $20(83.3 \%)$ cases in unspecified aetiology. Meningeal signs were present in 32 (71\%) cases in bacterial meningoencephalitis, $12(41.3 \%)$ cases in viral encephalitis and 14 (58.3\%) cases in unspecified aetiology. Focal neurological signs were present in $8(27.5 \%)$ cases of viral encephalitis, whereas $15(33.3 \%)$ cases had similar signs in bacterial meningoencephalitis and in 6 (25\%) cases in unspecified aetiology. $8(44.4 \%)$ cases with viral meningoencephalitis presented with GCS $<8$, whereas there were $6(33.3 \%)$ such cases in bacterial meningoencephalitis and $4(22.5 \%)$ cases in unspecified group (Table 2 ).

Serum sodium level was less than $130 \mathrm{mEq} / \mathrm{L}$ in 45 (45.9\%) cases, out of which 17 (37.8\%) died, $11(24.4 \%)$ recovered completely and $17(37.8 \%)$ developed sequelae. The outcome varied significantly $[\mathrm{p}=0.000]$ (Table 3 ).

Most common sequelae was seizure disorder (28.9\%) followed by weakness (11.8\%), extrapyramidal movement (9.2\%), aphasia $(9.2 \%)$, cranial nerve palsy $(9.2 \%)$ etc. Among the patients who developed sequelae $(n=25), 8$ $(32 \%)$ had multiple sequelae. Among the survivors $(n=76)$, $51(67.1 \%)$ had no sequelae (Table 4$)$.

Among 98 cases 51 (52\%) recovered completely, 25(25.5\%) developed sequelae and 22 (22.5\%) expired. Among children with viral encephalitis $(\mathrm{n}=29), 11(37.9 \%)$ recovered completely, 11 (37.9\%) developed sequelae and 7 $(24.2 \%)$ children died. Whereas in bacterial meningoencephalitis $(n=45) 31(69 \%)$ children recovered completely, 7 (15.5\%) developed sequelae and 7 (15.5\%) died. In the unspecified group $(n=24), 9$ (37.5\%) recovered completely, 7 (29.2\%) developed sequelae and 8 (33.3\%) died. The outcome varied significantly according to the aetiology of AES [ $p=0.034]$ (Table 5).

Maximum mortality was found in the group with GCS $<8$ (61.1\%) followed by shock (55.6\%) and those who required mechanical ventilation (55.3\%). Maximum sequelae was found in the group who required mechanical ventilation $(42.1 \%)$ followed by GCS $<8(33.3 \%)$ and with seizure (29\%). Among the signs and symptoms, least alarming sign was seizure and raised ICT where $61 \%$ patient had complete recovery and most alarming was those who required mechanical ventilation, where only $2.6 \%$ patients recovered followed by those presenting with GCS $<8$, where only $5.5 \%$ recovered completely. Outcome varied significantly with the presenting signs and symptoms $[\mathrm{p}=0.000]$ (Table 6 ). 


\begin{tabular}{|c|c|c|}
\hline Age Group (Years) & No. of Cases & Sex- Male, Female \\
\hline $1-5$ & $40(40.8 \%)$ & $23(57.5 \%) 17(42.5 \%)$ \\
\hline $5-9$ & $32(32.7 \%)$ & $19(59.4 \%) 13(40.6 \%)$ \\
\hline $9-12$ & $26(26.5 \%)$ & $15(57.7 \%) 11(42.3 \%)$ \\
\hline Total & $\mathbf{9 8 ( 1 0 0 \% )}$ & $\begin{array}{c}\mathbf{5 7}(\mathbf{5 8 . 2 \% )} \\
\mathbf{4 1}(\mathbf{4 1 . 8 \% )}\end{array}$ \\
\hline \multicolumn{2}{|c|}{ Table 1. Distribution of Cases according to Age and Sex }
\end{tabular}

Table 1. Distribution of Cases according to Age and Sex

\begin{tabular}{|c|c|c|c|c|c|c|}
\hline 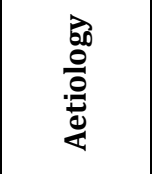 & 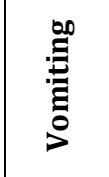 & 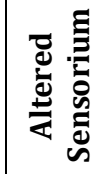 & 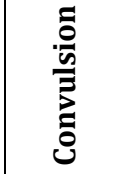 & 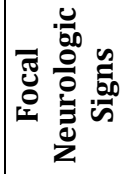 & o & $\begin{array}{l}\infty \\
v \\
\tilde{y}\end{array}$ \\
\hline $\begin{array}{c}\text { Bacterial } \\
(\mathrm{n}=45)\end{array}$ & $\begin{array}{c}41 \\
(91 \%)\end{array}$ & $\begin{array}{c}34 \\
(75.5 \%)\end{array}$ & $\begin{array}{c}27 \\
(60 \%)\end{array}$ & $\begin{array}{c}15 \\
(33.3 \%)\end{array}$ & $\begin{array}{c}32 \\
(71 \%)\end{array}$ & $\begin{array}{c}6 \\
(33.3 \%)\end{array}$ \\
\hline $\begin{array}{l}\text { Viral } \\
(n=29)\end{array}$ & $\begin{array}{c}26 \\
(89.6 \%)\end{array}$ & $\begin{array}{c}27 \\
(93 \%)\end{array}$ & $\begin{array}{c}26 \\
(89.6 \%)\end{array}$ & $\begin{array}{c}8 \\
(27.5 \%)\end{array}$ & $\begin{array}{c}12 \\
(41.3 \%)\end{array}$ & $\begin{array}{c}8 \\
(44.4 \%)\end{array}$ \\
\hline $\begin{array}{c}\text { Unspecified } \\
(\mathrm{n}=24)\end{array}$ & $\begin{array}{c}18 \\
(75 \%)\end{array}$ & $\begin{array}{c}20 \\
(83.3 \%)\end{array}$ & $\begin{array}{c}20 \\
(83.3 \%)\end{array}$ & $6(25 \%)$ & $\begin{array}{c}14 \\
(58.3 \%)\end{array}$ & $\begin{array}{c}4 \\
(22.3 \%)\end{array}$ \\
\hline
\end{tabular}

\begin{tabular}{|c|c|c|c|c|}
\hline $\begin{array}{c}\text { Sodium } \\
\text { Level } \\
(\mathrm{mEq} / \mathrm{L})\end{array}$ & Death & $\begin{array}{l}\text { Complete } \\
\text { Recovery }\end{array}$ & Sequelae & \multirow{5}{*}{$\begin{array}{c}\chi 2(4) \\
=29.07 \\
\mathrm{p}=0.000\end{array}$} \\
\hline$<130(n=45)$ & $17(37.8 \%)$ & $11(24.4 \%)$ & $17(37.8 \%)$ & \\
\hline $\begin{array}{c}130-135 \\
(n=46)\end{array}$ & $5(10.9 \%)$ & $36(78.3 \%)$ & $5(10.8 \%)$ & \\
\hline$>135(n=7)$ & --- & $4(57.2 \%)$ & $3(42.8 \%)$ & \\
\hline $\begin{array}{c}\text { Total } \\
(n=98)\end{array}$ & 22 & 51 & 25 & \\
\hline \multicolumn{5}{|c|}{ Table 3. Outcome in Relation to Serum Sodium Level } \\
\hline
\end{tabular}

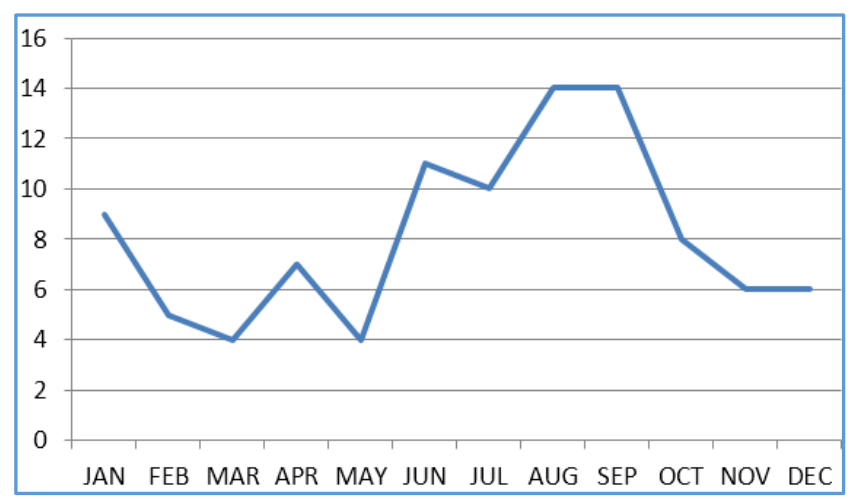

Figure 1. Monthly distribution of Cases

\begin{tabular}{|c|c|}
\hline Sequelae & No. of Cases \\
\hline Aphasia & $7(9.2 \%)$ \\
\hline Seizure disorder & $22(28.9 \%)$ \\
\hline Deafness & $4(5.2 \%)$ \\
\hline Behavioural disorder & $3(3.9 \%)$ \\
\hline Extrapyramidal movement & $7(9.2 \%)$ \\
\hline Memory loss & $3(3.9 \%)$ \\
\hline Weakness & $9(11.8 \%)$ \\
\hline Loss of vision & $3(3.9 \%)$ \\
\hline Cranial nerve palsy & $7(9.2 \%)$ \\
\hline No sequelae & $51(67 \%)$ \\
\hline Table 4. Development of Sequelae among Survivors (n=76)
\end{tabular}

Table 4. Development of Sequelae among Survivors ( $n=76)$

\begin{tabular}{|c|c|c|c|c|}
\hline Aetiology & $\begin{array}{l}\text { Complete } \\
\text { Recovery }\end{array}$ & Sequelae & Death & \multirow{5}{*}{$\begin{array}{c}\chi \\
2(4)=10 . \\
42, \\
p=0.034\end{array}$} \\
\hline $\begin{array}{c}\text { Bacterial } \\
(\mathrm{n}=45)\end{array}$ & $31(69 \%)$ & $7(15.5 \%)$ & $7(15.5 \%)$ & \\
\hline Viral $(n=29)$ & $11(37.9 \%)$ & $11(37.9 \%)$ & $7(24.2 \%)$ & \\
\hline $\begin{array}{c}\text { Unspecified } \\
(\mathrm{n}=24)\end{array}$ & $9(37.5 \%)$ & $7(29.2 \%)$ & $8(33.3 \%)$ & \\
\hline Total $(\mathrm{n}=98)$ & $51(52 \%)$ & $25(25.5 \%)$ & $22(22.5 \%)$ & \\
\hline
\end{tabular}

\begin{tabular}{|c|c|c|c|c|}
\hline $\begin{array}{l}\text { Signs and } \\
\text { Symptoms }\end{array}$ & $\begin{array}{l}\text { Complete } \\
\text { Recovery }\end{array}$ & Sequelae & Death & \multirow{6}{*}{$\begin{array}{c}\chi \\
{ }^{2}(8)=54.7, \\
p=0.000\end{array}$} \\
\hline $\begin{array}{l}\text { Seizure } \\
(\mathrm{n}=73)\end{array}$ & 45 (61.7\%) & $21(28.8 \%)$ & $7(9.5 \%)$ & \\
\hline $\begin{array}{c}\text { Raised ICT } \\
(\mathrm{n}=52)\end{array}$ & $32(61.5 \%)$ & $5(9.7 \%)$ & $15(28.8 \%)$ & \\
\hline $\begin{array}{l}\mathrm{GCS}<8 \\
(\mathrm{n}=18)\end{array}$ & $1(5.6 \%)$ & $6(33.3 \%)$ & $11(61.1 \%)$ & \\
\hline Shock $(n=9)$ & $2(22.2 \%)$ & $2(22.2 \%)$ & $5(55.6 \%)$ & \\
\hline $\begin{array}{c}\text { Mechanical } \\
\text { Ventilation } \\
\text { Required } \\
(\mathrm{n}=38)\end{array}$ & $1(2.6 \%)$ & $16(42.1 \%)$ & $21(55.3 \%)$ & \\
\hline Table 6. & & ekat & Ci $\quad=$ & tom \\
\hline
\end{tabular}

\section{DISCUSSION}

AES is associated with significant morbidity and mortality, particularly in a developing country like India. Infective aetiology remains the most common cause till date. Various studies have been conducted to find out the aetiology, but very few studies have emphasised on the predictors of morbidity and mortality, particularly from East India. The aim of this study was to find out the cause of AES in children, clinical features, short-term outcome and predictors of morbidity and mortality.

In our study, majority were males (58.2\%) and maximum cases were below 5 years $(40.8 \%)$. Previous Indian studies also demonstrated male preponderance and the most affected age group was also the same.(3,4) Maximum (50\%) cases occurred during monsoon season, which corroborates with the study by $\mathrm{P}$ Sharma et al(5) that also showed maximum number of cases during monsoon season (53.7\%).

We found that bacterial meningoencephalitis was the most common cause of AES followed by viral encephalitis. Our finding was consistent with the finding of Kumar et al.(6) They showed bacterial meningoencephalitis to be the most common cause (44.4\%) of AES, whereas viral encephalitis in $34.6 \%$ cases. The study by Singh et al(7) found that pyogenic meningitis was the most common cause $(42 \%)$ followed by non-JE viral encephalitis (25\%) and JE ( 18\%). In our study among all the patients JE was found in $21.4 \%$, whereas non-JE was found in $8 \%$ cases. However, Bokade et al(3) demonstrated that maximum number of cases were due to viral encephalitis (46.5\%). Others were due to pyogenic meningitis (22.1\%), cerebral malaria (15.9\%) and Tuberculous Meningoencephalitis (TBM) in $15.3 \%$ cases. We found $8.9 \%$ cases of TBM. Another study by Kirti Gupta et al(2) showed bacterial meningoencephalitis in $28.9 \%$ cases, viral meningoencephalitis in $23.3 \%$ cases and in $38.9 \%$ cases no aetiology were found. Among bacterial aetiology, they found Pneumococcus (30.8\%), Streptococcus pyogenes (15.4\%), Staphylococcus (7.6\%), Enteric meningoencephalitis (5.6\%) and TBM in $8.9 \%$ cases which are almost similar to our findings. Significant number of cases were of unknown 
aetiology, which were due to unavailability of required laboratory investigations, many non-infectious causes or due to presence of new virus.

In our study, the most common presenting symptom was vomiting followed by convulsion and altered sensorium. Vomiting was most common in bacterial meningoencephalitis (91\%). In comparison, altered sensorium was the most common presenting feature in viral encephalitis (93\%). Viral encephalitis presented with convulsion in $89.6 \%$ cases as compared to bacterial meningoencephalitis, where it was seen in $60 \%$ cases and in unspecified group it was $83.3 \%$ cases. Focal neurological signs were most common in bacterial meningoencephalitis (33.3\%) compared to viral encephalitis (27.5\%) and unspecified aetiology (25\%). Meningeal signs were most common in bacterial meningoencephalitis (71\%) compared to viral encephalitis $(41.3 \%)$ and unspecified group (58.3\%). Low GCS was more common in viral encephalitis (44.4\%) than other groups.

Previous study conducted by Singh et al(7) showed that fever and altered sensorium were most common presenting feature in AES followed by headache and vomiting. Convulsion was seen in $50 \%$ cases, whereas focal neurological signs were present in $9.3 \%$ cases. Altered sensorium was more common in viral encephalitis, which corroborates with our study.

Similarly, Kirti Gupta et al(2) showed that fever and altered sensorium were present in $100 \%$ cases. Seizure was present in $71.1 \%$ cases and vomiting in $35.6 \%$ cases, which were less than our study. Focal neurological signs were present in $5.6 \%$ cases and meningeal sign in $35.6 \%$ cases, which were also less than our study. They also showed seizure and GCS $<8$ were more common in viral aetiology and vomiting and meningeal signs were more common in bacterial meningoencephalitis, which are also seen in our study. Another study by P Sharma et al(5) showed that seizure was more common in viral meningoencephalitis (61.8\%) than bacterial meningoencephalitis (58.3\%), whereas meningeal signs were more common in bacterial meningoencephalitis $(66.7 \%)$ than viral encephalitis (52.9\%) which also corroborates with our study. In our study, clinical features present in JE were similar to those seen in other studies. $(7,8)$

In our study, maximum mortality was found in unspecified group (33.3\%) followed by viral encephalitis $(24.2 \%)$. Maximum sequelae were found in viral encephalitis (37.9\%) followed by cases with unspecified aetiology $(29.2 \%)$ and least sequelae was found in bacterial meningoencephalitis (15.5\%). Complete recovery was highest in bacterial meningoencephalitis (69\%), whereas it was almost same in unspecified and viral group (37\%). Similar result was shown by Bokade et al(3) in 2014. They found mortality in $19.3 \%$ cases, sequelae in $26.7 \%$ cases and complete recovery in $53.9 \%$ cases. But in their study maximum mortality was found in viral encephalitis (44.1\%) followed by bacterial meningitis (38.2\%). In contrast to our study, they found maximum sequelae in bacterial meningoencephalitis (61.7\%) followed by viral encephalitis (31.9\%). Our study corroborates with the study by Kirti Gupta et al(2) that showed highest mortality in the group with inconclusive aetiology (50\%) followed by viral group (25\%) and bacterial meningoencephalitis group (16.6\%).

We found hyponatraemia ( $\mathrm{Na}<130 \mathrm{mEq} / \mathrm{L})$ was significantly associated with mortality and morbidity. Similar result was also found by Sambasivam et al.(9) They showed significant mortality (23.3\%) with hyponatraemia.

In our study various risk factors for mortality were identified. GCS $<8$, shock and those requiring mechanical ventilation had highest mortality. Maximum sequelae were found in those requiring mechanical ventilation followed by those presenting with GCS $<8$ and with seizure. Complete recovery was maximum in those with seizure and raised ICT. Previous study by Bokade et al(3) showed that GCS $<8$ at the time of admission had 4.3 times greater risk of death as compared to those subjects who had GCS $\geq 8$ on presentation. Similarly, other variables like refractory seizure, shock and respiratory failure were other risk factors as seen in our study. Kirti Gupta et al(2) showed that GCS $<8$, shock, raised intracranial tension and respiratory failure were the risk factors associated with higher mortality. Meligy and his colleagues in Egypt in 2018(10) showed mechanical ventilation was a risk factor for fatality.

Some limitations were noted and must be acknowledged in this study. The number of the study participants was not high, thereby limiting power of the analysis. Being a tertiary care centre based study, referral bias could not be ruled out. Non-availability of specific investigations for many viral aetiologies of AES was another limiting factor. Also the children were not followed up for long-term complications and sequelae. Despite these limitations, we hope that our study would contribute in filling lacunae of our current understanding of AES in developing countries, mostly in eastern regions of India.

\section{CONCLUSION}

AES is associated with significant morbidity and high mortality, particularly in a developing country like India. With non-availability of many pathogen specific microbiological investigations, aetiological agents may remain elusive in a considerable number of cases. In our study, mortality was highest in unspecified group and sequelae was highest in viral encephalitis. GCS $<8$, shock, requirement of mechanical ventilation and hyponatraemia were independent predictors of mortality in children with AES.

\section{ACKNOWLEDGEMENTS}

We would like to thank the medical staff at Calcutta National Medical College for their support. We thank principal, School of Tropical Medicine and Hygiene for helping in the special investigations. We also thank Dr. Subhankar Mukherjee, Associate Professor, Department of Community Medicine for his statistical support.

\section{REFERENCES}

[1] Solomon T, Thao TT, Lewthwaite P, et al. A cohort study to assess the new WHO Japanese encephalitis surveillance standards. Bull World Health Organ 2008;86(3):178-86.

[2] Gupta K, Purani CS, Mandal A, et al. Acute febrile encephalopathy in children: a prospective study of clinical features, etiology, mortality, and risk factors from Western India. Journal of Neurosciences in Rural Practice 2018;9(1):19-25. 
[3] Bokade C, Gulhane R, Bagul A, et al. Acute febrile encephalopathy in children and predictors of mortality. J Clin Diagn Res 2014;8(8):PC09-11.

[4] Karmarkar SA, Aneja S, Khare S, et al. A study of acute febrile encephalopathy with special reference to viral etiology. Indian J Pediatr 2008;75(8):801-5.

[5] Sharma P, Sarmah BK, Kayastha P, et al. Clinical profi le of children with acute febrile encephalopathy in a tertiary health care center of Nepal. J Nepal Paediatr Soc 2015;35(3):224-30.

[6] Kumar R, Mathur A, Kumar A, et al. Virological investigations of acute encephalopathy in India. Archives of Disease in Childhood 1990;65(11):122730 .

[7] Singh RR, Chaudhary SK, Bhatta NK, et al. Clinical and etiological profile of acute febrile encephalopathy in eastern Nepal. Indian Journal of Pediatrics 2009;76(11):1109-11.
[8] Rayamajhi A, Singh R, Prasad R, et al. Clinicolaboratory profile and outcome of Japanese encephalitis in Nepali children. Ann Trop Paediatr 2006;26(4):293-301.

[9] Sambasivam E, Muthaiyan J, Mohan S, et al. Clinical profile and predictors of outcome in children admitted to PICU with acute encephalitis syndrome. International Journal of Contemporary Pediatrics 2017;4(4):1214-7.

[10] Meligy B, Kadry D, Draz IH, et al. Epidemiological profile of acute viral encephalitis in a sample of Egyptian children. Open Access Macedonian Journal of Medical Sciences 2018;6(2):423-9. 